JURNAL RESPIRASI

JR

Vol. 2 No. 1 Januari 2016

\title{
Organic Dust Toxic Syndrome (ODTS)
}

\author{
Deva Bachtiar, Agus Dwi Susanto \\ Departemen Pulmonologi dan Ilmu Kedokteran Respirasi, Fakultas Kedokteran, Universitas Indonesia RS Persahabatan, Jakarta
}

\begin{abstract}
Organic dust toxic syndrome (ODTS) was manifestation of some acute symptoms, (same with acute hypersensitivity pneumonitis or extrinsic allergic alveolitis) with initially by flu like syndrome that were fever, malaise, myalgia, dry cough, dyspnea, and headache after exposure of organic dust in several hours. Etiology of ODTS usually from agricultural environment like hay, grain, straw, moldy, pollen, mycotoxins, bacteria and endotoxin. Organic dust toxic syndrome (ODTS) spontaneous recovery without sequele if patients avoid organic dust exposure immediately and avoid recurrent exposure. The best treatment were supportive therapy and preventive therapy from that etiology.
\end{abstract}

Key words: ODTS, pneumonitis hipersensitif

Correspondence: Deva Bachtiar, Departemen Pulmonologi dan Ilmu Kedokteran Respirasi, Fakultas Kedokteran, Universitas Indonesia RS Persahabatan, Jakarta.

\section{PENDAHULUAN}

Organic dust toxic syndrome (ODTS) disebut juga toxic alveolitis dan pulmonary mycotoxocis dalam kepustakaan kesehatan baru-baru ini. ${ }^{1-3}$ Sebelumnya ODTS dikenal sebagai atypical famer's lung, silo unloader's syndrome dan inhalation fever (mill fever, humidifier fever atau grain fever). ${ }^{4-8}$ Gejala yang terjadi pada ODTS biasanya berupa demam yang timbul setelah terinhalasi debu organik. Gejala yang timbul tergantung dari tempat kerjanya. Beberapa laporan disebutkan bahwa kejadian ODTS lebih sering pada para pekerja yang berhubungan dengan pertanian dan produksi pertanian termasuk juga lingkungan perternakan. ${ }^{1}$

Debu organik merupakan agents (alat perantara) kompleks yang dapat menyebabkan berbagai perubahan patofisiologi. Bernardo Ramazzini dari Italia, sejak awal abad ke 18 telah mengamati peran debu organik dari serat sayuran dan biji-bijian terhadap terjadinya kelainan paru pada para pekerja di pertanian. Debu organik di daerah pertanian ternyata membawa risiko kelainan paru para pekerja, terutama pekerja anak. ${ }^{9}$ Debu organik tersebut dapat berasal dari rumput kering (hay), biji-bijian (grain), jerami (straw), jamur (moldy) dan bakteri. ${ }^{7}$ Banyaknya penyakit paru yang terjadi akibat pekerjaan, membuat
ODTS penting untuk diketahui sebagai salah satu penyakit paru akibat kerja. Tinjauan pustaka ini akan membahas lebih dalam mengenai tentang ODTS.

\section{Definisi}

Organic dust toxic syndrome merupakan sekumpulan gejala akut menyerupai pneumonitis hipersensitif (HP) akut atau alveolitis alergi ekstrinsik yang dimulai dengan gejala akut (flu like sindrom) yaitu demam, menggigil, malaise, mialgia, batuk kering, sesak napas dan sakit kepala setelah beberapa jam terpajan debu organik. Lamanya pajanan debu organik sampai menimbulkan gejala bervariasi dari berbagai kepustakaan disebutkan 3-8 jam, 4-9 jam dan ada pula yang menyebutkan 3-12 jam setelah terpajan debu organik dalam jumlah besar. Walaupun gejala ODTS ini ringan, secara umum dapat dipicu oleh satu atau beberapa gejala yang akan menjadi berat oleh karena pajanan debu organik yang tidak umum dan berulang. Namun demikian penyakit ini dapat sembuh dengan sendirinya dalam 36-48 jam berikutnya tanpa gejala sisa. Bahkan kepustakaan lain menyebutkan dapat sembuh dalam waktu 24 jam. ${ }^{6-14}$

\section{Epidemiologi}

Insidens ODTS sulit untuk ditegakkan. Diketahui bahwa para pekerja di pertanian sangat rentan terjadinya ODTS, hal ini disebabkan karena petani berhubungan langsung 
dengan debu dan terpajan debu organik hampir setiap hari. Penelitian yang dilakukan di Swedia pada para petani ditemukan insidens febrile reactions ODTS sekitar 100 per 10000 petani pertahunnya. ${ }^{13}$ Prevalensi ODTS pada petani di Inggris sekitar 3-5\%. ${ }^{9}$ Penelitian tentang gejala dan penyakit obstruktif paru pada 4.793 petani di Eropa didapatkan bahwa ODTS sekitar 19,4\% lebih tinggi dari kejadian asma 5,4\%. ${ }^{15}$ Sedangkan di Amerika kejadian ODTS lebih dari $40 \%$ pada para petani. ${ }^{8}$ Kejadian ODTS pada para petani di Skandinavia dilaporkan 3-4 kasus per 10.000 petani pertahun. ${ }^{6}$

\section{Etiologi}

Inhalasi debu organik yang berat terjadi pada pekerja pertanian. Artinya bahwa petani mempunyai risiko lebih sering untuk terpajan debu organik. Konsentrasi yang tinggi dari debu organik dapat terjadi selama bekerja di peternakan babi, pengeringan padi dan pengolahan produksi pertanian lainnya. Debu organik yang berasal dari lingkungan pertanian dapat berupa partikel rumput kering (hay), bijibijian (grain), jerami (straw), jamur (moldy), serbuk sari (pollen), mycotoxins, bakteri dan endotoksin. Sedangkan debu organik yang berasal dari kandang perternakan dapat berupa partikel yang berasal dari kulit, rambut, bulu burung/ ayam dan kotoran ternak. Semuanya ini tergantung dimana, kapan dan bagaimana debu organik tersebut diproduksi (musim, lokasi geografik dan kelembaban)., ${ }^{4,5,10}$

National Board Occupatinal Safety and Health membuat nilai ambang batas pajanan debu organik di udara yaitu $5 \mathrm{mg} / \mathrm{m}^{3}$. Nilai ini merupakan batasan pajanan maksimal konsentrasi debu organik yang dapat diterima. ${ }^{10}$ Penyakit yang ditimbulkan dari pajanan debu organik tergantung dari komponen biologi dan konsentrasi yang jauh di bawah $5 \mathrm{mg} / \mathrm{m}^{3}$. Konsentrasi debu organik lebih berat yang berisi komponen partikular berbahaya tidak dapat diterima. Lingkungan pertanian yang dapat juga menimbulkan masalah kesehatan yaitu komponen yang berasal dari gas pupuk seperti ammonia dan hydrogen sulphide ammonia dapat menyebabkan iritasi dan paralisis silia membran mukosa. Pajanan debu organik yang disertai dengan ammonia dapat meningkatkan jumlah debu di saluran napas bawah. ${ }^{3,10}$ Partikel debu ukuran kurang dari $5 \mu \mathrm{m}$ akan terhirup melalui udara masuk ke dalam alveoli yang kemudian dapat menyebabkan inflamasi paru. ${ }^{2}$

\section{Patogenesis}

Patogenesis terjadinya ODTS belum banyak diketahui, penelitian baru-baru ini menyebutkan bahwa ODTS dapat terjadi karena terinhalasi endotoksin yang berasal dari debu organik seperti jerami, rumput kering, makanan ternak yang disimpan dalam gudang gandum, debu padi-padian, mikroorganisme dan jamur (gambar 1). Pada umumnya para petani terserang ODTS setelah mereka bertugas membersihkan tempat penyimpanan gandum, padi dan memberikan makanan ternak (makanan ternak yang terkontaminasi jamur). Beberapa penelitian mengatakan bahwa endotoksin merupakan respons utama untuk terjadinya respons inflamasi atau disebutkan juga mycotoxins turut menyebabkan inflamasi in vivo dan in vitro dari dinding sel. ${ }^{16}$

Organic dust toxic syndrome berasal dari proses inhalasi debu organik atau aerosol yang berisi sejumlah besar mikroorganisme. ${ }^{2}$ Organic dust toxic syndrome merupakan hasil dari respons sistem imum innate (alamiah) pada inhalasi debu organik. Reaksi ini tidak mengikutkan sensitisasi sebelumnya dan respons tidak spesifik pada system imun adaptive. Keterlibatan netrofil pada paru setelah terpajan debu organik merupakan proses kompleks. Kemotaksis netrofil dibantu oleh beberapa mekanisme, termasuk penyembuhan langsung dan respons pada debu organik dari padi-padian. Selanjutnya netrofil dilepaskan dari makrofag alveolar dan sel epithelia brokus pada subtabtansia kemotaksis, termasuk juga rangkaian komponen komplemen C5a dan interlukin-8 (IL-8). ${ }^{1}$

Dimulai dengan proses inhalasi toksin yang memicu pelepasan serangkaian mediator. Sitokin dapat membawa sel inflamasi ke jalan napas dan paru yang menyebabkan terjadinya proses mekanisme klinis. Demam merupakan gejala utama ODTS disebabkan karena endotoksin. Endotoksin adalah lipopolisakarida yang berasal dari dinding sel bakteri gram negatif. Sitokin pirogenik dilepaskan dalam respons pajanan debu organik termasuk
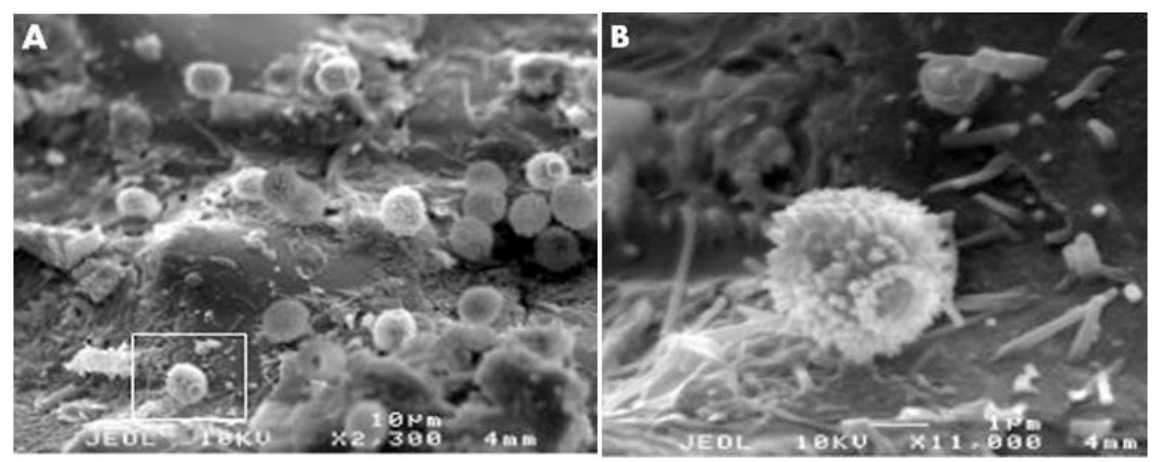

Gambar 1. ${ }^{16}$ (A) Spora jamur terlihat dengan electron micrographs

(B) Bakteri yang berasal dari rumput dan buah-buahan 


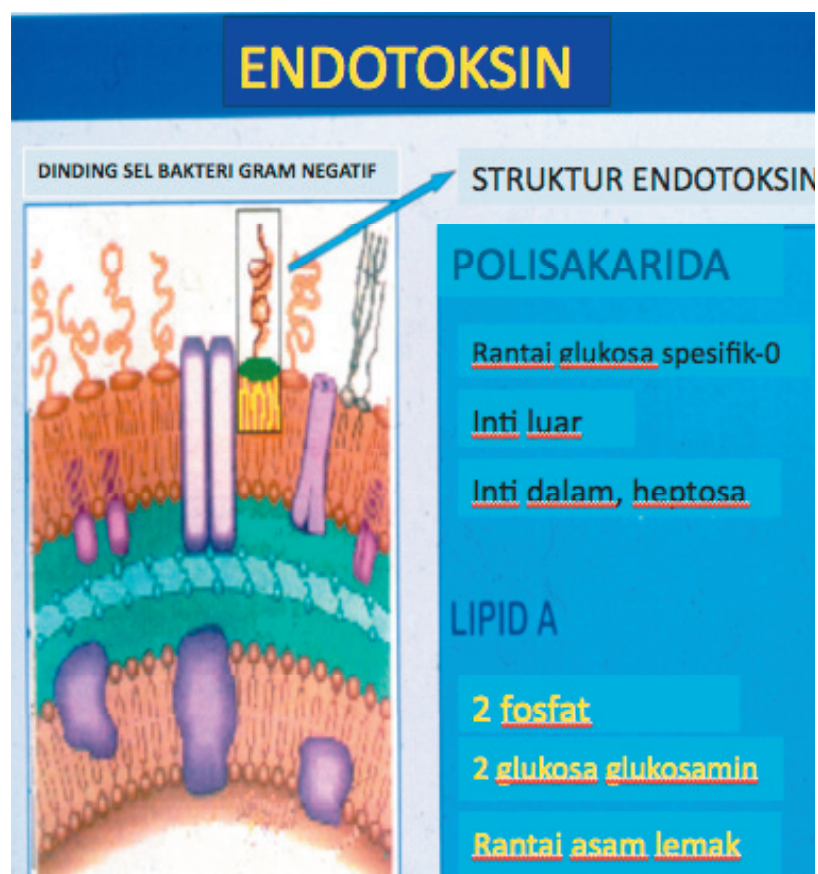

Gambar 2. Endotoksin ${ }^{3}$

pelepasan IL-1, IL-6 dan TNF- $\alpha$ (tumor necrosis factor) dari sel paru. Ini menyerupai pelepasan mediator panas dan efek inflamasi lainnya. Pelepasan sitokin pada penelitian seorang yang terpajan jamur kayu dan keterlibatannya untuk meningkatkan ODTS. ${ }^{111}$ Gambar endotoksin tersebut dapat dilihat pada gambar 2. Beberapa hipotesis yang menyatakan bahwa ODTS adalah toksik didukung oleh beberapa pernyataan berikut: ${ }^{2}$ (1) Jangka waktu antara pajanan dengan munculnya gejala yang terlalu singkat sehingga bukan menjadi ciri-ciri proses infeksi; (2) Tidak adanya kebutuhan akan pajanan/sensitisasi sebelumnya, (3) Tidak terdapatnya serum antibody (presipitin) untuk agen atau sumber etiologi, (4) Dugaan terdapatnya material airborne dalam jumlah banyak pada sebagian besar kasus, (5) Suseptibilitas ODTS pada individu-individu dengan pajanan yang sama, (6) Kesembuhan spontan dalam waktu 24 jam setelah tidak ada pajanan.

Batasan pajanan endotoksin yang dianggap aman untuk kesehatan yang direkomendasikan oleh Dutch Expert Committee on Ocupational Standars (DECOS) adalah 50 $\mathrm{EU} / \mathrm{m}^{3} \cdot{ }^{16}$ Data Selengkapnya dapat dilihat berdasarkan nilai konsentrasi endotoksin yang memberikan efek pada kesehatan terutama pada saluran napas adalah: ${ }^{17}(1)$ 200-500 EU/M3; iritasi membran mukosa, (2) 1.000-2.000 EU/M3; akut bronkokontriksi, (3) 10.000-20.000 EU/M3; Organic dust toxic syndrome

Menurut WHO 1996 ukuran debu partikel yang membahayakan berukuran 0,1-5 atau 10 mikron sedangkan Depkes mengisyaratkan bahwa ukuran debu yang membahayakan berkisar 0,1-10 mikron. ${ }^{17}$ Mekanisme debu masuk ke dalam paru diketahui berawal dari inhalasi debu melalui hidung maupun mulut terus masuk kesaluran napas sesuai dengan nilai ambang batasnya. Partikel debu yang berukuran lebih dari 10 mikron hanya dapat masuk sampai hidung sedangkan partikel debu yang berukuran 5-10 mikron akan masuk terus ke trakea dan berhenti di bronkus, sementara partikel debu yang berukuran kurang dari 5 mikron terus masuk melalui jalan pernapasan sampai ke alveoli. Mekanisme masuknya partikel debu dapat kita lihat dari gambar 3.

Data dari penelitian juga menyebutkan ukuran debu dapat mencapai target organ sebagai berikut: ${ }^{17,18}$ (1) 5-10 mikron; tertahan oleh saluran pernafasan bagian atas, (2) 3-5 mikron; tertahan oleh saluran pernafasan bagian tengah, (3) 1-3 mikron; sampai dipermukaan alveoli, (4) 0,5-1 mikron; hinggap dipermukaan alveoli/selaput lendir sehingga menyebabkan fibrosis paru, (5) 0,1-0,5 mikron; melayang dipermukaan alveoli.

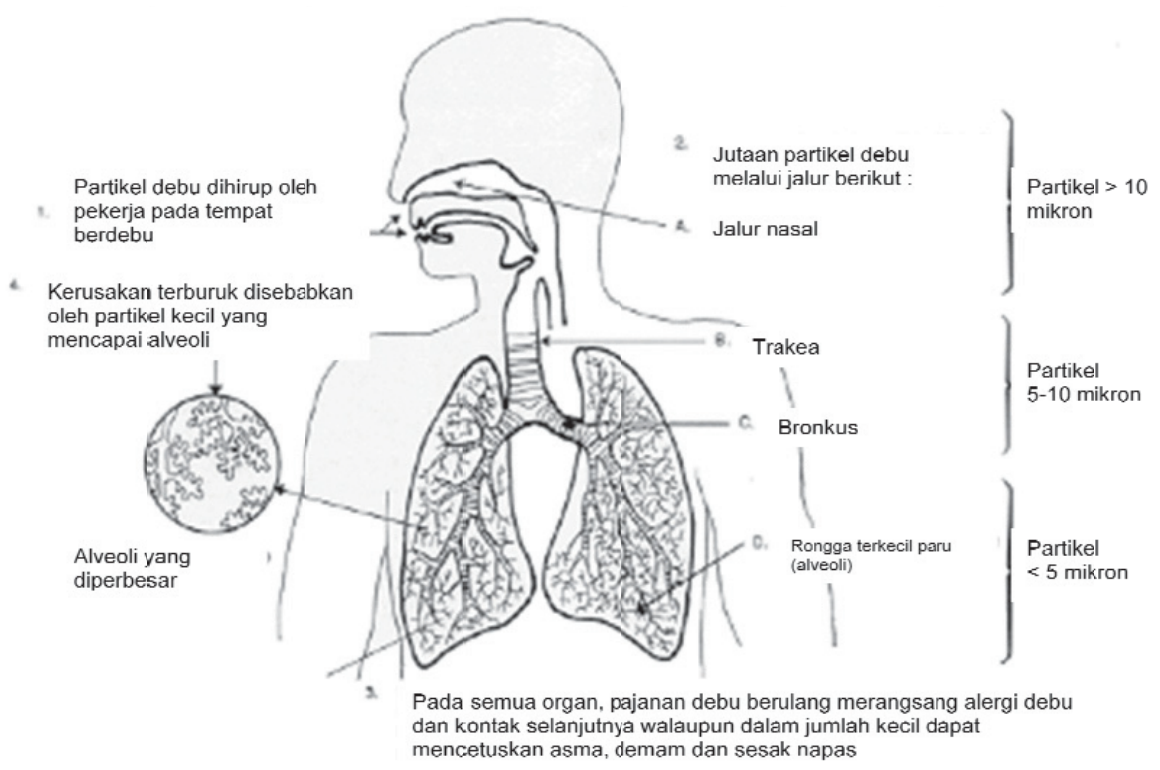

Gambar 3. Mekanisme masuknya partikel debu. ${ }^{8}$ 


\section{Gambaran Klinis}

Para pekerja dilahan pertanian mengalami ODTS setelah mereka terinhalasi debu yang telah terkontaminasi material organik. Gejala akan timbul 4-12 jam setelah mereka terpajan debu organik. Secara umum gejala yang ditimbulkan menyerupai flu-like symptoms seperti sakit kepala, menggigil, badan terasa lemah, batuk kering, sesak napas, dada tertekan, nyeri otot dan demam. Pada pemeriksaan fisis didapatkan hipoksemia dan pada paru kadangkala ditemukan ronki dan mengi. Semua gambaran klinis ini akan menghilang dengan sendirinya dalam waktu 36-48 jam tanpa disertai gejala sisa jika disertai dengan menghindari pajanan debu organik tersebut. ${ }^{6}$

Biji-bijian (grain) merupakan debu organik yang sangat kompleks partikelnya, mengandung partikel organik dan non organik. Semuanya dapat terpajan dengan mudah dan tergantung dari ukuran partikelnya. Partikelnya dapat ditemukan di sistem pernapasan paling dalam. Grain dust secara biologi berasal dari kombinasi: ${ }^{18}$ (1) Material tanaman, (2) Jamur dan spora jamur, (3) Sebagian serangga dan kotorannya, (4) Bakteri, (5) Endotoksin, (6) Tanah.

Contoh di bawah ini merupakan sumber yang berisiko terpajan debu organik: ${ }^{19}$

Pertanian

pengolahan padi, jerami hasil panen

Gula tebu, gudang penyimpanan padi atau ternak

Binatang kandang perternakan babi Peternakan ayam

Proses pembuangan kotoran dan lumpur Pembuatan kompos

Industri proses olahan kayu Fermentasi Proses biotehnologi

Bangunan terkontaminasi oleh humidifiers, pertumbuhan mikroba

Sedangkan contoh penyebab terbanyak debu organik: ${ }^{19}$ Tumbuhan; tannins, histamine, plicatic acid, alkaloids, cytochalasins.

Binatang; protein, enzyme

Mikroba; endotoxins, protease, mycotoxins, $1-3-\beta-D-$ glucans

Selama musim panen kebanyakan orang akan mengalami berbagai masalah kesehatan karena terpajan debu organik. Seringkali akan timbul iritasi saluran napas atau masalah kesehatan lainnya. Pada musim panen terdapat debu organik dengan kombinasi partikel yaitu debu yang banyak dengan ukuran partikel $1-15 \mathrm{mg} / \mathrm{m}^{3}$ dan endotoksin. Gejala umum atau yang biasanya ditimbulkan berupa batuk, kadangkadang disertai dahak dan berlanjut dengan gejala ODTS seperti yang sudah disebutkan diatas yaitu gejala yang menyerupai flu like symptom. ${ }^{18}$

\section{Evaluasi Klinis}

Demam terjadi pada fase akut dan ini menyebabkan terjadinya lekositosis jumlah lekosit bisa sampai 25000 dengan dominan peningkatan sel netrofil. ${ }^{19}$ Evaluasi pasien ODTS pada pemeriksaan fisis dan fungsi paru adalah normal. Foto thoraks normal kadang kala ditemukan juga patchy infiltrat pada keadaan yang lebih berat. Pemeriksaan analisis gas darah kadang ditemukan alkalosis respiratorik disebabkan hiperventilasi. Pemeriksaan bronkoskopi dalam keadaan akut memperlihatkan inflamasi mukosa bronkial yang luas dan ditemukan jumlah sel netrofil yang lebih dominan. Akan tetapi pada keadaan pemulihan ditemukan peningkatan sejumlah sel limfosit. ${ }^{2,20}$ Pemeriksaan bronkoskopi setelah 1-4 minggu terutama sel limfosit. ${ }^{19}$

Penyakit yang dapat ditimbulkan oleh debu organik dapat berupa: ${ }^{19}$ (1) Bronkitis dan pneumonitis; toxic pneumonitis (demam, sindroma ODTS), inflamasi jalan napas (inflamasi membrane mukosa), dan bronkitis kronik, (2) Pneumonitis Hipersensitif (alveolitis alergi), (3) Asma; rhinitis dan konjungtifitis.

\section{Penatalaksanaan}

Penatalaksanaan pasien ODTS ini bersifat suportif. Analgetik dapat diberikan apabila terdapat keluhan nyeri dada dan nyeri otot. Demikian juga untuk antiperetik diberikan bila diperlukan. Obat batuk juga dapat diberikan bila keluhan batuknya berat dan mengganggu. Pemberian antibiotik bukan merupakan indikasi, kortikosteroid juga tidak dapat memperpendek waktu dan gejala ODTS. Penatalaksanaan terbaik adalah mencegah dengan memberikan informasi kepada individu tentang risiko terkena ODTS dan cara pencegahannya dengan proteksi pernapasan dari terkontaminasi lingkungan pertanian. Penyakit ini pada umumnya sembuh secara spontan tanpa meninggalkan sequelae (gejala sisa). Gejala akan berulang bila kembali terpajan debu organik. 2,20

\section{Diagnosis Banding}

Organik dust toxic syndrome sulit dibedakan dengan akut pneumonitis hipersensitif. Riwayat terpajan, kumpulan gejala yang tepat dan ditemukan pada beberapa orang dapat membantu menegakkan diagnosis ODTS. Kalaupun terdapat hubungan antara ODTS dengan HP hal ini belum dapat dijelaskan. ${ }^{2}$ Pneumonitis hipersensitif (HP) atau dikenal dengan alveolitis alergik ekstrinsik merupakan bagian dari kelompok ILD (interstitial lung disease) yang sebagian besar diketahui penyebabnya akibat pajanan partikel organik, inorganic atau berhubungan dengan penyakit kolagen vascular. Tabel 1 dibawah ini memperlihatkan perbedaan antara ODTS dengan HP. ${ }^{19}$

\section{KESIMPULAN}

Organic dust toxic syndrome (ODTS) merupakan kumpulan gejala akut menyerupai pneumonitis hipersensitif 
Tabel 1. Perbedaan antara ODTS dengan $\mathrm{HP}^{19}$

\begin{tabular}{|c|c|c|}
\hline & ODTS & HP \\
\hline Kelainan & $\begin{array}{l}\text { ringan (dapt sembuh } \\
\text { sendiri) }\end{array}$ & $\begin{array}{l}\text { interstitial lung } \\
\text { disease }\end{array}$ \\
\hline Dominan sel & netrofil & limfosit \\
\hline Proses inflamasi & $\begin{array}{l}\text { tidak menginduksi } \\
\text { pelepasan antigen }\end{array}$ & $\begin{array}{l}\text { melibatkan proses } \\
\text { antigen-antibody }\end{array}$ \\
\hline Foto thoraks & normal & terdapat infiltrate \\
\hline $\begin{array}{l}\text { Pemeriksaan } \\
\text { paru }\end{array}$ & $\begin{array}{l}\text { sebagian kecil } \\
\text { obstruksi }\end{array}$ & $\begin{array}{l}\text { restriksi disertai } \\
\text { ronki }\end{array}$ \\
\hline Stadium penyakit & hanya akut & $\begin{array}{l}\text { akut, subakut, } \\
\text { kronis }\end{array}$ \\
\hline Kalsifikasi & & $\begin{array}{l}\text { allergic } \\
\text { occupational } \\
\text { disease } \\
\text { akut inhalasi debu } \\
\text { organic }\end{array}$ \\
\hline
\end{tabular}

akut atau alveolitis alergi ekstrinsik yang dimulai dengan gejala akut (flu like symptom) yaitu demam, menggigil, malaise, mialgia, batuk kering, sesak napas dan sakit kepala setelah terpajan beberapa jam debu organik.

Penyebab ODTS diketahui berasal dari lingkungan pertanian berupa partikel rumput kering (hay), biji-bijian (grain), jerami (straw), jamur (moldy), serbuk sari (pollen), mycotoxins, bakteri dan endotoksin.

Organic dust toxic syndrome (ODTS) dapat sembuh spontan tanpa meninggalkan gejala sisa bila pasien segera menghindari pajanan dengan debu organik dan menghindari pajanan berulang.

Pengobatan yang terbaik adalah dengan memberikan terapi suportif dan pencegahan terhadap penyebabnya.

\section{DAFTAR PUSTAKA}

1. Susanna G, Von E, Colene I, Lynette M. Organic dust toxic Syndrome: A non infectious febrile illness after exposure to the hog barn environment. J Swinw Health Prod 2005; 13: 273-6.

2. Cormier Y, Schuyler M. Hypersensitivity pneumonitis and oerganic dust toxic syndromes. In: Berrnstein L, Chan-Yeung M, Malo JL,
Bernstein DI, editors. Asthma in the workplace, $3^{\text {rd }}$ ed. New York: Taylor \& francis; 2006. p. 713-35.

3. Anna R. Organic dust toxic syndrome among farmers. BJ of Industrial Medicine 1989; 46: 233-8.

4. Emanuel DA, Wenzel FJ, Lowton BR. Pulmonary mycotoxycosis. Chest 1975; 67: 293-7.

5. May JJ, Stallones L, Darrow D, Pratt DS. Organic dust toxicity (pulmonary mycotoxicosis) associated with silo unloading. Thorax 1986; 41: 919-23.

6. Castranova V, Robinson VA, Frazer D. Pulmonary reactions to organic dust exposures: Development of an animal model. Environ Health Perspect 1996; 104: 41-53.

7. Malmberg P, Andersen-Rask A, Rosenhall L. Exposure to microorganisms associated with allergic alveolitis and febrile reactions to mold dust famers. Chest 1993; 103: 1202-9.

8. Steven A, Von Essen S, Jacobitz K, Crouch R, Litner C. Do poison centers diagnostic dust toxix syndrome? J Toxicology 2003; 41: $115-7$.

9. Dawud Y. Dampak pajanan debu organik di tempat kerja: gejala Respirasi kronik, status atopi dan fungsi ventilasi. Disajikan pada pertemuan Ilmiah Khusus XI-2006 Batam 2006.

10. The following General recommendations are issued by the international board of occupational safety and health on the implementation of the work environment act. SFS 1977: 1160.

11. Vogelzang FJ, van der Gulden JWJ, Folgering H. Organic dust toxic syndrome in swine confinement farming. AMJ 1999; 35: 332-4.

12. Malmberg P, Rask AA, Hoglund S, Kolmodin H, Read GJ. Incidence of organic dust toxic syndrome and allergic alveolitis in Swedish farmers Int Arch Allergy Appl Immunol 1988; 87: 47-54.

13. The National Farm Medicine Center is a service of Marshfield Clinic, Marshfield, Wisconsin For more information, call us at 1-800-6626900 or visit our web site at http://www.marshfieldclinic.org/nfmc 910-026.

14. Monso’ E, Magarolas R, Radon K, Danuser B, Iversen M. Respiratory symptoms of obstructive lung disease in European crop farmers. AMJ Respir Crit care Med 2000; 162: 1246-50.

15. Smit LAM, Wouter IM, Hobo MM, Eduar W, Doekes G, Heederik D. Agricultural seed dust as a potential cause of organic dust toxic syndrome. Occup Environ Med 2006; 63: 59-67.

16. Malberg P, Rask-Anderson A, Ludhom M, Palmemgren U. Can spores from molds and actinomycetes cause an organic dust toxic syndrome reaction? Am J Ind Med 1990; 17: 109-10.

17. Wiwiek Pudjiastusi. Debu sebagai bahan pencemar yang membahayakan kesehatan kerja. Pusat kesehatan kerja departemen kesehatan RI. 2002.

18. Hagmar L, Schtz A, Hallberg, Sjohlm A. Health effects of exposure to endotoxins and organic dust in poulty slaughter-house wokers. Int Arch Occup Environ Health 1990; 62: 159-164.

18. David LS, Ryon, William NR. Encyclopedia of occupasional Health and safety: Disease caused by respiratory irritants and toxic chemical fourth ed. 1998; p. 1012-26.

20. National Institute of occupational safety and health, departemen of health and human service. Request for assistance in preventing organic dust toxic syndrome. SW Wasington DC april 1994. 